\title{
PENGARUH PENGGUNAAN LISTRIK PASCABAYAR DAN TINGKAT PENJUALAN TERHADAP PIUTANG USAHA PADA PT. PLN (PERSERO) RAYON TANJUNG BATU
}

\author{
${ }^{1}$ Ferawati, ${ }^{2}$ Febri Susanto ${ }^{3}$, Fauzan Haqiqi \\ ${ }^{1}$ Program Studi Akuntansi, Fakultas Ilmu Sosial dan Humaniora, Universitas Karimun, \\ Provinsi Kepulauan Riau, Indonesia \\ Email : fera.universitaskarimun@gmail.com \\ ${ }^{2}$ Program Studi Akuntansi, Fakultas Ilmu Sosial dan Humaniora, Universitas Karimun, \\ Provinsi Kepulauan Riau, Indonesia \\ Email : febri.susanto@gmail.com \\ ${ }^{3}$ Program Studi Akuntansi, Fakultas Ilmu Sosial dan Humaniora, Universitas Karimun, \\ Provinsi Kepulauan Riau, Indonesia \\ Email : fauzanhaqiqi1986@gmail.com
}

\begin{abstract}
Abstrak
Penelitian ini bertujuan untuk mengetahui pengaruh antara penggunaan listrik pascabayar dan tingkat penjualan terhadap piutang usaha secara parsial dan simultan pada PT. PLN (Persero) Rayon Tanjung Batu. Jenis penelitian ini bersifat kuantitatif dengan menggunakan data sekunder yang diperoleh dari laporan internal perusahaan. Teknik sampling yang digunakan adalah non-probability sampling yaitu teknik sampling dengan menggunakan pertimbangan khusus atau (purposive sampling) dengan menggunakan laporan yang diambil dari tahun 2014-2018. Dari pertimbangan dan kriteria yang disesuaikan untuk tujuan penelitian didapat sampel 24 sampel penelitian dengan rentang waktu 2 tahun (2016-2017).

Teknik analisa data yang digunakan dalam penelitian ini menggunakan metode verifikatif dengan pendekatan kuantitatif. Hasil uji t menunjukkan bahwa pascabayar berpengaruh terhadap piutang usaha dibuktikan dengan nilai t hitung sebesar 3.1088 lebih besar daripada $t$ Tabel sebesar 2,07961 dan dengan tingkat sig $0.00<(\alpha) 0.05$ (tingkat signifikan yang disyaratkan), hasil uji t menunjukkan bahwa tingkat penjualan tidak berpengaruh terhadap piutang usaha hal ini dibuktikan dengan nilai t hitung sebesar -1,10254 lebih kecil daripada t Tabel sebesar 2,07961 dan dengan tingkat sig $0.283 \mathrm{sig}>(\alpha) 0.05$ (tingkat signifikan yang disyaratkan). Secara simultan pascabayar dan tingkat penjualan berpengaruh terhadap piutang usaha dibuktikan dengan nilai $\mathrm{F}$ hitung sebesar 5,858 lebih besar daripada F Tabel sebesar 3,47 dan dengan tingkat sig 0.00 yang berarti nilai sig $<(\alpha) 0.05$ (tingkat signifikan yang disyaratkan).
\end{abstract}

Kata kunci : Penjualan, Listrik Pascabayar, dan Piutang usaha. 


\section{PENDAHULUAN}

Perkembangan dibidang perekonomian selama ini telah banyak membawa akibat yang cukup pesat dalam dunia usaha, sehubungan dengan itu banyak perusahaan baru berdiri dan kembalinya perusahaan yang direhabilitasi, maka berakibat timbulnya persaingan yang ketat diantara perusahaan-perusahaan tersebut. Baik itu persaingan antar perusahaan sejenis maupun perusahaan yang tidak sejenis.

Perusahaan dalam keberadaannya sebagai unit organisasi, pada umumnya didirikan dengan tujuan untuk memperoleh keuntungan dengan jalan menyediakan barang atau jasa yang sesuai dengan kebutuhan masyarakat. Keuntungan bisa diperoleh apabila perusahaan dapat mencapai tingkat penjualan yang maksimal.

\section{Tabel 1.1}

Tingkat Penjualan PT.PLN (Persero) Rayon Tanjung Batu Periode 2014-2018

\begin{tabular}{|c|c|c|c|c|c|}
\hline \multirow[t]{2}{*}{ Bulan } & \multicolumn{5}{|c|}{ Tahun } \\
\hline & 2014 & 2015 & 2016 & 2017 & 2018 \\
\hline Januari & Rp 2.542.274.309 & Rp 2.687.760.326 & $\operatorname{Rp} 2.520 .995 .931$ & Rp 2.660.747.153 & Rp 2.319.936.637 \\
\hline Februari & Rp 2.542.274.309 & Rp 2.480.434.381 & Rp 2.458.977.500 & Rp 2.431.198.702 & Rp 2.242.754.332 \\
\hline Maret & Rp 2.665.283.022 & Rp 2.732.566.183 & Rp 2.398.208.943 & Rp 2.758.230.794 & Rp 2.474.932.628 \\
\hline April & Rp 2.837.317.190 & Rp 2.681.780.320 & Rp 2.710.596.054 & Rp 2.687.150.899 & Rp 2.401.554.319 \\
\hline Mei & Rp 2.643.324.821 & Rp 2.698.235.355 & Rp 2.565.198.586 & Rp 2.902.602.228 & \\
\hline Juni & Rp 2.696.942.457 & Rp 2.674.426.582 & $\operatorname{Rp} 2.449 .284 .719$ & Rp 2.864.005.663 & \\
\hline Juli & Rp 2.800.781.311 & $\operatorname{Rp} 2.826 .355 .224$ & $\operatorname{Rp} 2.530 .556 .453$ & Rp 2.891.052.843 & \\
\hline Agustus & Rp 2.584.869.522 & Rp 2.725.034.195 & Rp 2.571.836.381 & Rp 2.854.285.280 & \\
\hline September & Rp 2.755.272.520 & Rp 2.613.826.669 & Rp 2.521.184.409 & Rp 2.725.197.414 & \\
\hline Oktober & Rp 2.804.490.121 & Rp 2.693.824.825 & $\operatorname{Rp} 2.521 .184 .409$ & Rp 2.785.205.257 & \\
\hline November & $\operatorname{Rp} 2.741 .808 .262$ & Rp 2.573.146.064 & Rp 2.441.841.390 & Rp 2.414.738.389 & \\
\hline Desember & Rp 2.776.350.521 & Rp 2.573.146.064 & $\operatorname{Rp} 2.593 .090 .421$ & Rp 2.480.683.134 & \\
\hline
\end{tabular}

Sumber : Laporan PT. PLN (Persero) Rayon Tanjung Batu 
Tabel 1.1 memperlihatkan tingkat penjualan PT. PLN (Persero) Rayon Tanjung Batu periode 2014-2018, secara umum tingkat penjualan perusahaan cenderung menurun dari tahun ke tahun. Tingkat penjualan merupakan jumlah total yang dihasilkan dari kegiatan penjualan barang atau jasa. Dari kegiatan tersebut, semakin besar jumlah penjualan yang dihasilkan perusahaan, maka semakin besar pula kemungkinan laba yang diperoleh perusahaan. Oleh sebab itu penjualan merupakan salah satu hal penting yang harus dievaluasi untuk mencegah kemungkinan perusahaan mengalami kerugian.

Secara umum penjualan terdiri dari dua jenis yaitu penjualan tunai dan penjualan kredit. Tetapi sebagian perusahaan memberikan fasilitas kredit bagi pelanggannya. Penjualan kredit merupakan transaksi antara perusahaan dengan pembeli, perusahaan mempunyai tagihan sesuai jangka waktu tertentu yang mengakibatkan timbulnya piutang dank as di aktiva.

Berawal dari aktivitas penjualan secara kredit, maka timbul yang namanya piutang. Piutang bisa dikatakan sebagai asset yang materil, karena umumnya timbul akibat dilakukannya penjualan secara kredit.

Piutang adalah salah satu jenis transaksi akuntansi yang mengurusi penagihan konsumen yang berhutang pada suatu perusahaan, atau suatu organisasi untuk barang dan layanan yang telah diberikan pada konsumen.

\section{Tabel 1.2}

Tingkat Piutang Usaha PT.PLN (Persero) Rayon Tanjung Batu Periode 2014-2018

\begin{tabular}{|l|r|r|r|r|r|}
\hline \multirow{2}{*}{ Bulan } & \multicolumn{5}{|c|}{ Tahun } \\
\cline { 2 - 6 } & \multicolumn{1}{|c|}{$\mathbf{2 0 1 4}$} & $\mathbf{2 0 1 5}$ & $\mathbf{2 0 1 6}$ & $\mathbf{2 0 1 7}$ & $\mathbf{2 0 1 8}$ \\
\hline Januari & $\mathrm{Rp}$ & $\mathrm{Rp} 8.090 .587$ & $\mathrm{Rp}$ & $\mathrm{Rp}$ & $\mathrm{Rp}$ \\
& 11.465 .720 & & 39.728 .184 & 12.925 .958 & 6.261 .151 \\
\hline Februari & $\mathrm{Rp}$ & $\mathrm{Rp} 22.197 .707$ & $\mathrm{Rp}$ & $\mathrm{Rp}$ & $\mathrm{Rp}$ \\
& 8.691 .481 & & 55.151 .856 & 17.882 .120 & 7.644 .894 \\
\hline Maret & $\mathrm{Rp}$ & $\mathrm{Rp} 2.644 .236$ & $\mathrm{Rp}$ & $\mathrm{Rp}$ & $\mathrm{Rp}$ \\
& 11.457 .896 & & 24.211 .730 & 10.972 .577 & 5.132 .087 \\
\hline April & $\mathrm{Rp}$ & $\mathrm{Rp} 17.295 .851$ & $\mathrm{Rp}$ & $\mathrm{Rp}$ & $\mathrm{Rp}$ \\
& 9.495 .854 & & 24.084 .838 & 15.996 .060 & 7.982 .688 \\
\hline Mei & $\mathrm{Rp}$ & $\mathrm{Rp} 23.203 .979$ & $\mathrm{Rp}$ & $\mathrm{Rp}$ & \\
& 1.618 .536 & & 31.101 .851 & 10.379 .533 & $\mathrm{Rp}$ \\
\hline Juni & $\mathrm{Rp}$ & $\mathrm{Rp} 11.485 .294$ & $\mathrm{Rp}$ & & \\
\hline
\end{tabular}




\begin{tabular}{|c|c|c|c|c|}
\hline & 2.424 .345 & & 12.190 .480 & 11.969 .563 \\
\hline Juli & $\begin{array}{r}\mathrm{Rp} \\
14.629 .827\end{array}$ & Rp 19.847.417 & $\begin{array}{r}\mathrm{Rp} \\
22.311 .012\end{array}$ & $\begin{array}{r}\mathrm{Rp} \\
9.534 .383\end{array}$ \\
\hline Agustus & $\begin{array}{r}\mathrm{Rp} \\
5.163 .395\end{array}$ & Rp 31.097.951 & $\begin{array}{r}\mathrm{Rp} \\
17.430 .037\end{array}$ & $\begin{array}{r}\mathrm{Rp} \\
10.377 .405\end{array}$ \\
\hline September & $\begin{array}{r}\mathrm{Rp} \\
6.550 .994\end{array}$ & Rp 13.560.839 & $\begin{array}{r}\mathrm{Rp} \\
20.315 .046\end{array}$ & $\begin{array}{r}\mathrm{Rp} \\
10.424 .145\end{array}$ \\
\hline Oktober & $\begin{array}{r}\mathrm{Rp} \\
10.973 .573\end{array}$ & Rp 12.070.303 & $\begin{array}{r}\mathrm{Rp} \\
6.627 .365\end{array}$ & $\begin{array}{r}\mathrm{Rp} \\
2.417 .519\end{array}$ \\
\hline November & $\begin{array}{r}\mathrm{Rp} \\
10.823 .671\end{array}$ & Rp 24.453.555 & $\begin{array}{r}\mathrm{Rp} \\
2.931 .564\end{array}$ & $\begin{array}{r}\mathrm{Rp} \\
1.431 .976\end{array}$ \\
\hline Desember & $\begin{array}{r}\mathrm{Rp} \\
63.976 .629\end{array}$ & Rp 81.954.881 & $\begin{array}{r}\mathrm{Rp} \\
977.663\end{array}$ & $\begin{array}{r}\mathrm{Rp} \\
0\end{array}$ \\
\hline
\end{tabular}

Sumber : Laporan PT. PLN (Persero) Rayon Tanjung Batu

Tabel 1.2 memperlihatkan tingkat piutang usaha PT. PLN (Persero) Rayon Tanjung Batu periode 2014-2018, secara umum tingkat piutang usaha perusahaan mengalami naik dan turun secara tidak teratur. Karena piutang usaha ada tenggang waktu, maka perusahaan harus menunggu saat terjadinya pelunasan piutang. Apabila pelunasan piutang tidak lancer, maka akan mengganggu posisi keuangan, karena modal kerja banyak tertahan dalam bentuk piutang tersebut. Pengelolaan piutang merupakan unsur penting dalam kelangsungan hidup suatu usaha, karena piutang merupakan sumber keuangan atau kas perusahaan yang digunakan untuk pembiayaan operasional perusahaan.

Manajemen piutang sangat penting bagi perusahaan yang produknya secara kredit, hal ini menyangkut masalah pengendalian jumlah piutang, pengendalian dan pengumpulan piutang, serta evaluasi kebijakan kredit yang diterapkan perusahaan, sehingga terhindar dari risiko terjadinya piutang tak tertagih.

Untuk itu PT. PLN (Persero) meluncurkan inovasi terbaru yaitu Listrik Prabayar (LPB) merupakan pelayanan PLN dalam menjual listrik dengan cara pelanggan membayar diawal. Pelanggan membeli sejumlah nilai tertentu sebelum menggunakan listrik dari PLN. Listrik prabayar diluncurkan untuk menjawab keluhan masyarakat. Antara lain soal melonjaknya pemakaian listrik, sering menerima keluhan tentang pembacaan meteran yang tidak benar, kedatangan petugas pencatatan meteran yang dianggap mengganggu, juga soal pemadaman listrik akibat pelanggan telat bayar. Disisi perusahaan dengan layanan listrik prabayar, diharapkan tidak ada lagi piutang usaha, seperti dalam sistem pascabayar. 
Tabel 1.3

Tingkat Penggunaan Listrik Pascabayar PT.PLN (Persero) Rayon Tanjung Batu Periode 2014-2018

\begin{tabular}{|c|c|c|c|c|c|c|c|c|c|c|}
\hline \multirow{3}{*}{ Bulan } & \multicolumn{10}{|c|}{ Tahun } \\
\hline & \multicolumn{2}{|c|}{2014} & \multicolumn{2}{|c|}{2015} & \multicolumn{2}{|c|}{2016} & \multicolumn{2}{|c|}{2017} & \multicolumn{2}{|c|}{2018} \\
\hline & Paska & Pra & Paska & Pra & Paska & Pra & Paska & Pra & Paska & Pra \\
\hline Januari & 10.960 & $\begin{array}{r}4.76 \\
2\end{array}$ & 9.075 & $\begin{array}{r}8.44 \\
0\end{array}$ & 8.678 & 9.922 & 8.447 & 11.480 & 6.250 & 14.905 \\
\hline Februari & 10.960 & $\begin{array}{r}4.76 \\
2\end{array}$ & 9.061 & $\begin{array}{r}8.53 \\
5\end{array}$ & 8.662 & 10.017 & 8.432 & 11.617 & 6.213 & 15.006 \\
\hline Maret & 10.680 & $\begin{array}{r}5.22 \\
0\end{array}$ & 9.048 & $\begin{array}{r}8.54 \\
5\end{array}$ & 8.634 & 10.176 & 8.414 & 11.722 & 6.189 & 15.108 \\
\hline April & 10.649 & $\begin{array}{r}5.26 \\
4\end{array}$ & 8.983 & $\begin{array}{r}8.74 \\
5\end{array}$ & 8.621 & 10.351 & 8.373 & 11.840 & 6.169 & 15.262 \\
\hline Mei & 10.570 & $\begin{array}{r}5.71 \\
3\end{array}$ & 8.972 & $\begin{array}{r}8.79 \\
9\end{array}$ & 8.607 & 10.502 & 8.190 & 12.110 & & \\
\hline Juni & 10.439 & $\begin{array}{r}5.84 \\
1\end{array}$ & 8.908 & $\begin{array}{r}9.07 \\
3\end{array}$ & 8.572 & 10.623 & 8.108 & 12.298 & & \\
\hline Juli & 10.391 & $\begin{array}{r}6.35 \\
6\end{array}$ & 8.876 & $\begin{array}{r}9.23 \\
8\end{array}$ & 8.556 & 10.689 & 7.918 & 12.565 & & \\
\hline Agustus & 10.341 & $\begin{array}{r}6.40 \\
5\end{array}$ & 8.835 & $\begin{array}{r}9.32 \\
6\end{array}$ & 8.537 & 10.773 & 7.839 & 12.743 & & \\
\hline $\begin{array}{l}\text { Septembe } \\
\mathrm{r}\end{array}$ & 9.801 & $\begin{array}{r}6.96 \\
9\end{array}$ & 8.771 & $\begin{array}{r}9.53 \\
0\end{array}$ & 8.515 & 10.880 & 7.777 & 12.898 & & \\
\hline Oktober & 9.777 & $\begin{array}{r}7.06 \\
0\end{array}$ & 8.749 & $\begin{array}{r}9.62 \\
4\end{array}$ & 8.515 & 10.880 & 7.704 & 13.083 & & \\
\hline $\begin{array}{l}\text { Novembe } \\
\mathrm{r}\end{array}$ & 9.732 & $\begin{array}{r}7.39 \\
5\end{array}$ & 8.726 & $\begin{array}{r}9.73 \\
8\end{array}$ & 8.484 & 11.105 & 6.723 & 14.172 & & \\
\hline $\begin{array}{l}\text { Desembe } \\
\mathrm{r}\end{array}$ & 9.626 & $\begin{array}{r}7.78 \\
7\end{array}$ & 8.726 & $\begin{array}{r}9.73 \\
8\end{array}$ & 8.466 & 11.319 & 6.708 & 14.337 & & \\
\hline
\end{tabular}

Sumber : Laporan PT. PLN (Persero) Rayon Tanjung Batu 
Dari Tabel 1.3 memperlihatkan penggunaan listrik pascabayar dan prabayar PT. PLN (Persero) Rayon Tanjung Batu periode 2014-2018, secara umum penggunaan listrik prabayar perusahaan mengalami kenaikan yang cukup stabil dari tahun ke tahun, dan penurunan penggunaan listrik pascabayar, tapi tidak menyertakan penurunan tingkat piutang secara signifikan.

\section{TINJAUAN PUSTAKA}

Menurut Peraturan Menteri ESDM Nomor 27 Tahun 2017 tentang Tingkat Mutu Pelayanan dan biaya yang terkait dengan penyaluran tenaga listrik oleh perusahaan PT. PLN (Persero), menyebutkan dua sistem layanan yang disediakan oleh PT. PLN (Persero) kepada public, yaitu sistem listrik pascabayar dan listrik prabayar. Sistem listrik pascabayar adalah sistem yang pertama kali digunakan oleh konsumen di Indonesia.

Tarif tenaga listrik regular (Pascabayar) adalah tenaga listrik disediakan oleh PT. PLN (Persero) yang dibayarkan setelah pemakaian tenaga listrik oleh konsumen (Permen ESDM No. 27, 2017:3), melalui sistem ini pelanggan dapat menggunakan energy listrik terlebih dahulu dan membayar pada bulan berikutnya. PT. PLN (Persero) akan melakukan pencatatan meteran di lokasi tempat tinggal atau tempat usaha pelanggan, menghitung dan menerbitkan rekening yang harus dibayar pelanggan, dan melakukan penagihan kepada pelanggan yang terlambat membayar. Besaran biayanya sesuai dengan jumlah pemakaian selama sebulan.

Sedangkan sistem listrik prabayar adalah layanan baru yang disediakan oleh PT. PLN (Persero), penggunaan tariff tenaga listrik prabayar menurut Peraturan Menteri EDSM Nomor 27 Tahun 2017 adalah "tariff tenaga listrik disediakan oleh PT. PLN (Persero) yang dibayarkan sebelum pemakaian tenaga listrik oleh konsumen". Pemanfaatan listrik untuk kebutuhan seharihari dilakukan dengan cara membeli token atau pulsa listrik terlebih dahulu dengan nominal bervariatif di tempat yang telah ditentukan oleh PT. PLN (Persero), seperti di bank-bank yang bekerja sama dengan PT. PLN (Persero), PPOB (Payment Point Online Bank), dan mitra lain yang bekerja sama. Asal mula diterapkannya sistem prabayar di Indonesia adalah dengan mengadopsi sistem listrik prabayar di negara Afrika.

\subsection{Penggunaan Listrik Pascabayar}

Penggunaan listrik merupakan kebutuhan pokok sehari-hari masyarakat suatu negara. Untuk itu penggunaan listrik diatur dalam Peraturan Menteri ESDM Nomor 27 Tahun 2017 tentang Tingkat Mutu Pelayanan dan biaya yang terkait dengan penyaluran tenaga listrik oleh perusahaan PT. PLN (Persero), menyebutkan Tingkat Mutu Pelayanan tenaga listrik yang disediakan oleh PT. PLN (Persero) berisi indikator mutu pelayanan sebagai berikut :

a. tegangan tinggi di titik pemakaian dengan satuan kilovolt $(\mathrm{kV})$;

b. tegangan menengah di titik pemakaian dengan satuan kilovolt $(\mathrm{kV})$;

c. tegangan rendah di titik pemakaian dengan satuan volt (v);

d. frekuensi di titik pemakaian dengan satuan hertz; 
e. lama gangguan dengan satuan jam/bulan/konsumen;

f. jumlah gangguan dengan satuan kali/bulan/konsumen;

g. kecepatan pelayanan sambungan baru tegangan menengah dengan satuan hari kerja;

h. kecepatan pelayanan sambungan baru tegangan rendah dengan satuan hari kerja;

i. kecepatan pelayanan perubahan daya tegangan menengah dengan satuan hari kerja;

j. kecepatan pelayanan perubahan daya tegangan rendah dengan satuan hari kerja;

k. kecepatan menanggapi pengaduan gangguan dengan satuan jam;

1. kesalahan pembacaan $\mathrm{kWh}$ meter dengan satuan kali/triwulan/konsumen; dan waktu korelasi kesalahan rekening dengan satuan hari kerja.

\subsection{Penjualan}

Secara umum penjualan dapat didefinisikan sebagai suatu kegiatan transaksi yang dilakukan oleh kedua belah pihak atau lebih dengan menggunakan alat pembayaran yang sah. Dalam suatu perusahaan penjualan merupakan salah satu fungsi pemasaran yang sangat penting dalam mencapai sebuah tujuan perusahaan yaitu memperoleh laba untuk menjaga kelangsungan hidup perusahaan yang merupakan sumber pendapatan dalam melakukan transaksi jual dan beli. Semakin besar penjualan maka semakin besar pula pendapatan yang diperoleh perusahaan tersebut.

Menurut M. Nafarin (2006:60) bahwa : "Penjualan adalah proses menjual, padahal yang dimaksud penjualan dalam laporan laba rugi adalah hasil menjual atau hasil penjualan (sales) atau jualan".

Sedangkan menurut Warren Reeve Fess (2006:300) bahwa: "Penjualan adalah jumlah yang dibebankan kepada pelanggan untuk barang dagang yang dijual, baik secara tunai maupun kredit". Dan menurut Kusnadi (2003:300) bahwa: "Penjualan (sales) adalah sejumlah uang yang dibebankan kepada pembeli atas barang atau jasa yang dijual".

Dari penjelasan di atas dapat disimpulkan bahwa penjualan adalah suatu proses pembuatan dan cara untuk mempengaruhi pribadi agar terjadi pembelian (penyerahan) barang atau jasa yang ditawarkan berdasarkan harga yang telah disepakati oleh kedua belah pihak atau lebih yang terkait baik dibayar secara tunai maupun kredit.

\subsection{Piutang Usaha}

Istilah piutang timbul karena adanya kebijakan penjualan kredit di dalam perusahaan. Menurut James C. Van Horne dan John M. Wachowicsz, Jr (1997:258): "Piutang adalah jumlah uang yang dipinjam dari perusahaan oleh pelanggan yang telah membeli barang atau jasa secara kredit". Penjualan kredit ini tidak segera menghasilkan penerimaan kas pada saat penjualan dilakukan, tetapi menimbulkan piutang dan akan berubah mejadi kas pada saat terjadi pelunasan piutang oleh pelanggan. Piutang tersebut meliputi semua klaim dalam bentuk uang terhadap perorangan atau organisasi.

Selanjutnya pengertian piutang menurut Lukman Syamsudin (2007:255) adalah "Piutang adalah tagihan yang timbul karena adanya transaksi secara kredit oleh perusahaan kepada langganannya. Penjualan kredit yang pada akhirnya akan menimbulkan hak penagihan atau piutang kepada langganan, sangat erat hubungannya dengan persyaratan-persyaratan kredit yang diberikan. Sekalipun pengumpulan piutang 
sering kali tidak tepat waktu yang sudah ditentukan, namun sebagian besar dari piutang tersebut akan terkumpul dalam jangka waktu kurang dari satu tahun. Dengan alasan itulah, maka piutang dimasukan sebagai salah satu komponen dalam aktiva lancar perusahaan.

Dalam praktik bisnis, konsumen pada umumnya lebih menyukai jika perusahaan menjual barang atau jasanya secara kredit dengan alasan pembayaran dapat ditunda walaupun pada kenyataan biasanya hasil penjualan kredit lebih besar dari hasil penjualan tunai. Dalam kondisi seperti ini pihak manajemen dituntut untuk dapat memperhitungkan seberapa besar piutang yang tak tertagih. Berdasarkan data tersebut, pihak manajemen mendapatkan masukan untuk menentukan kebijakan dalam pemberian kredit.

Menurut Manullang (2005:38) faktor yang mempengaruhi piutang adalah :

1. Volume penjualan kredit

Makin besar proporsi penjualan kredit dari total penjualan maka jumlah investasi dalam piutang juga demikian, artinya perusahaan harus menyediakan investasi yang lebih besar dalam piutang dan meski beresiko semakin besar, profitabilitasnya juga akan meningkat.

2. Syarat pembayaran kredit

Syarat pembayaran dapat berupa ketat atau lunak. Apabila perusahaan menetapkan pembayaran kredit yang ketat, artinya keselamatan kredit lebih diutamakan dari profitabilitasnya. Syarat pembayaran yang ketat antara lain tampak dari batas waktu pembayaran yang pendek dan pembebanan bunga yang berat untuk pembayaran piutang yang terlambat.

3. Ketentuan tentang pembatasan pembeli

Dalam penjualan secara kredit, perusahaan dapat menetapkan batas maksimal atau plafon bagi kredit yang diberikan kepada pelanggan, makin besar pula dana yang diinvestasikan ke dalam piutang.

4. Kebijakan dalam penagihan piutang

Kebijakan penagihan piutang secara aktif maupun pasif, dapat dilakukan oleh perusahaan. Perusahaan juga berharap agar pelanggan menyetor pembayaran hutang tepat waktu. Kebijakan ini ditempuh dengan cara memungut secara langsung atau memberi peringatan dengan mengirim surat kepada pelanggan.

5. Kebiasaan pembayaran pelanggan

Sebagian pelanggan mempunyai kebiasaan membayar dengan menggunakan kesempatan cash discount, dan sebagian lagi tidak demikian. Kebiasaan pelanggan membayar dengan cash discount atau sesudahnya mempunyai efek terhadap besarnya investasi dalam piutang, sebab diskon periode menyebabkan dana yang 
tertanam dalam piutang lebih cepat cair dan memperkecil investasi dalam piutang. Namun resiko piutang tak tertagih pada perusahaan semakin kecil.

\section{METODE PENELITIAN}

\section{.1 Rancangan Penelitian}

Penelitian ini menggunakan jenis penelitian asosiatif yaitu penelitian yang bertujuan untuk mengetahui pengaruh ataupun juga hubungan antara dua variabel atau lebih. Penelitian ini mempunyai tingkatan tertinggi dibandingkan dengan deskriptif dan komparatif karena dengan penelitian ini dapat dibangun suatu teori yang dapat berfungsi untuk menjelaskan, meramalkan dan mengontrol suatu gejala.

\subsection{Jenis dan Sumber Data}

Pada penelitian ini menggunakan jenis data kuantitatif yaitu data yang berwujud angka atau bilangan dan bersumber dari data sekunder atau data dari sumber yang telah ada yaitu data laporan keuangan PT. PLN (Persero) Rayon Tanjung Batu Periode 20142018.

\subsection{Populasi dan Sampel}

Populasi dalam penelitian ini adalah data laporan internal perusahaan pada PT. PLN (Persero) Rayon Tanjung Batu dari tahun 2014 sampai dengan tahun 2018 sebanyak 52 data.

Teknik yang digunakan untuk pengambilan sampel yaitu teknik non probability sampling, yang merupakan teknik penentuan sampel dengan kriteria dan pertimbangan tertentu yang disesuaikan dengan tujuan penelitian. Adapun kriteria dalam penelitian ini adalah sebagai berikut :

1. Data yang diambil merupakan laporan internal perusahaan yang terdapat di sistem PT. PLN (Persero) Rayon Tanjung Batu yang merupakan sumber informasi terbaru, berupa laporan tingkat penjualan, laporan jumlah pengguna listrik pascabayar dan laporan piutang usaha, yang diambil pada periode 2016-2017.

2. Data yang diambil adalah data yang sudah disetujui oleh pihak perusahaan untuk diambil oleh peneliti.

3. Dalam laporan tersebut terdapat grafik yang stabil.

Berdasarkan pada kriteria pengambilan sampel yang disebutkan diatas, terdapat 24 data yang memenuhi kriteria yang telah ditentukan.

\subsection{Teknik Pengumpulan Data}

Sebagai bahan penyusunan dan pembahasan penelitian ini menggunakan studi dokumen merupakan jenis pengumpulan data yang meneliti berbagai macam dokumen yang berguna untuk bahan analisis yaitu data yang diperoleh dari laporan perusahaan.

\subsection{Identifikasi Variabel}

Adapun variabel-variabel yang digunakan dalam penelitian ini dibagi menjadi dua macam yaitu :

1. Variabel independen / bebas (X)

Variabel independen merupakan variabel yang mempengaruhi atau menjadi sebab perubahannya atau timbulnya variabel dependen, Sugiyono (2009:39). Dalam 
penelitian ini yang menjadi variabel independen adalah penggunaan listrik pascabayar dan tingkat penjualan.

2. Variabel dependen / terikat (Y)

Menurut Sugiyono (2012:59) variabel terikat merupakan variabel yang dipengaruhi atau yang menjadi akibat, karena adanya variabel bebas. Dalam hal ini variabel yang dependen / terikat yang akan diteliti adalah tingkat piutang usaha.

\subsection{Teknik Analisis Data}

Analisis pada penelitian ini dilakukan dengan menggunakan analisis kuantitatif. Data kuantitatif bersumber dari laporan keuangan PT. PLN (Persero) Rayon Tanjung Batu. Analisis data dalam penelitian ini menggunakan Regresi Linier Berganda. Sedangkan untuk pengolahan data menggunakan perangkat lunak (software) statistic SPSS (statistic package for social sciences) versi 23. Data-data tersebut dianalisis dengan menggunakan tahapan uji asumsi klasik (uji normalitas, uji multikolinearitas, uji heterokedastisitas, dan uji autokorelasi) dan uji hipotesis (uji t, uji F, dan uji adjusted $R$ square).

\section{HASIL DAN PEMBAHASAN}

\subsection{Hasil Uji Asumsi Klasik}

Sebelum melakukan uji hipotesis, terlebih dahulu melakukan uji asumsi klasik. Hal tersebut berguna untuk melihat apakah data telah terdistribusi dengan normal dengan uji normalitas dan untuk melihat apakah penelitian tersebut terjadi multikolinearitas, autokorelasi, dan heteroskedastisitas atau tidak. Uji asumsi klasik sebagai berikut :

\section{a. Hasil Uji Normalitas}

Uji normalitas berguna untuk melihat apakah data telah terdistribusi normal atau tidak. Pengujian normalitas menggunakan metode analisis grafik normal probability plot. Hasil uji yang dilakukan untuk mengetahui normalitas, dari model regresi penelitian ini dapat dilihat pada gambar dibawah ini :

\section{Gambar 4.1}

Grafik Normal Probability Plot 




Sumber : Data Olahan (2018)

Berdasarkan gambar diatas terlihat grafik plot, dimana terlihat titik-titik menyebar dan mengikuti garis diagonalnya, sehingga dapat disimpulkan bahwa model regresi memenuhi asumsi normalitas.

b. Hasil Uji Multikolinearitas

Uji multikolinearitas bertujuan untuk melihat apakah pada model regresi ditemukan adanya korelasi antar variabel independen. Hasil pengujian multikolinearitas dapat dilihat pada tabel dibawah ini :

Tabel 4.1

Hasil Uji Multikolinearitas

\begin{tabular}{|c|c|c|c|}
\hline \multirow[t]{2}{*}{ Model } & \multicolumn{2}{|c|}{ Collinearity Statistics } & \multirow[t]{2}{*}{ Kesimpulan } \\
\hline & Tolerance & VIF & \\
\hline (Constant) & & & \\
\hline Pascabayar & ,989 & 1,011 & Tidak Terjadi Multikolinearitas \\
\hline Penjualan & ,989 & 1,011 & Tidak Terjadi Multikolinearitas \\
\hline
\end{tabular}

Sumber : Data Olahan (2018)

Dari tabel 4.1 menunjukkan bahwa tidak ada variabel yang memiliki Variance Inflation Factor (VIF) kurang dari 10 dan nilai tolerance lebih dari 0.10 dalam pengujian model regresi. Dari data tersebut dapat disimpulkan bahwa tidak ada multikolinearitas antar variabel independen yang digunakan dalam model regresi.

c. Hasil Uji Autokorelasi

Uji autokorelaso bertujuan untuk menguji apakah dalam model regresi linier terdapat korelasi antara kesalahan pengganggu pada periode sebelumnya. Biasanya autokorelasi ini muncul akibat adanya observasi yang berurutan sepanjang waktu berkaitan satu sama lainnya. Hasil uji autokorelasi dapat dilihat pada tabel dibawah ini: 


\section{Tabel 4.2}

Hasil Uji Autokorelasi

Model Summary

\begin{tabular}{|l|r|r|r|r|r|}
\hline Model & R & R Square & $\begin{array}{c}\text { Adjusted } \\
\text { R Square }\end{array}$ & $\begin{array}{c}\text { Std. Error of } \\
\text { The Estimate }\end{array}$ & $\begin{array}{c}\text { Durbin- } \\
\text { Watson }\end{array}$ \\
\hline 1 &, $598^{\mathrm{a}}$ &, 358 &, 297 & 10851938,847 & 1,929 \\
\hline
\end{tabular}

a. Predictors: (Constant), Penjualan, Pascabayar

b. Dependent Variable: Piutang

Sumber : Data Olahan (2018)

Dari hasil output di atas didapat nilai DW yang dihasilkan dari model regresi adalah 1,929 maka tidak terjadi autokorelasi.

d. Hasil Uji Heteroskedastisitas

Pengujian ini bertujuan untuk menguji apakah setiap model regresi tidak terjadi ketidaksamaan variance dari residual pengamatan anatar satu pengamatan dengan pengamatan lain. Hasil pengujian heteroskedastisitas dapat dilihat pada gambar berikut ini :

\section{Gambar 4.2}

Hasil Uji Heteroskedastisitas Scatterplot

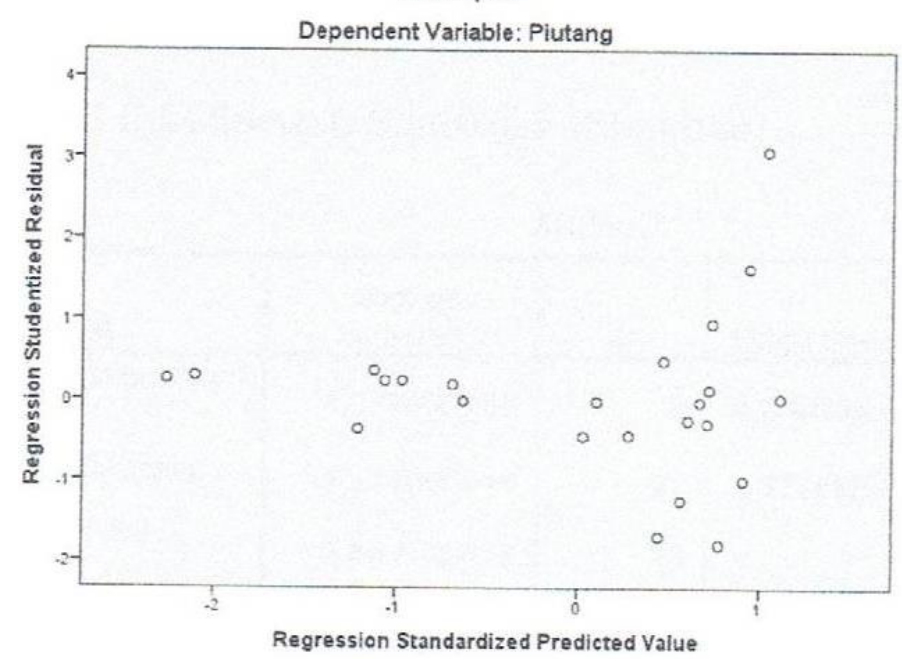

Sumber : Data Olahan (2018)

Dari grafik scatterplot terlihat bahwa titik-titik menyebar secara acak dan tidak membentuk suatu pola tertentu serta tersebar di atas maupun di bawah angka nol pada sumbu Y, sehingga dapat disimpulkan bahwa tidak terjadi heteroskedastisitas pada model regresi, sehingga model regresi layak dipakai untuk memprediksi berdasarkan masukan variabel independennya.

\subsection{Hasil Regresi Linier Berganda}

Berdasarkan hasil perhitungan dengan SPSS 23 diperoleh persamaan regresi linier berganda sebagaimana yang tersaji pada tabel 4.3 sebagai berikut : 
Tabel 4.3

Hasil Uji Regresi Linier Berganda

Coefficients $^{\mathrm{a}}$

\begin{tabular}{|c|c|c|c|c|c|}
\hline \multirow[b]{2}{*}{ Model } & \multicolumn{2}{|c|}{ Unstandardized Coefficients } & $\begin{array}{l}\text { Standardized } \\
\text { Coefficients }\end{array}$ & \multirow[b]{2}{*}{$\mathrm{t}$} & \multirow[b]{2}{*}{ Sig. } \\
\hline & $\mathrm{B}$ & Std. Error & Beta & & \\
\hline $1 \quad$ (Constant) & $-50379859,099$ & 52574077,193 & &,- 958 & ,349 \\
\hline Pascabayar & 12900,666 & 4149,713 &, 546 & 3,109 & ,000 \\
\hline Penjualan &,- 015 & ,014 &,- 194 & $-1,103$ & 283 \\
\hline
\end{tabular}

a. Dependent Variable : Piutang

Sumber : Data Olahan (2018)

Berdasarkan tabel 4.3, maka persamaannya dapat dimasukkan ke dalam persamaan regresi berganda sebagai berikut :

$$
Y=-50379859,099+12900,666 X_{1}-0,015 X_{2}
$$

Keterangan :

$$
\begin{aligned}
& \mathrm{Y}=\text { Piutang usaha } \\
& \mathrm{X}_{1}=\text { Penggunaan listrik pascabayar } \\
& \mathrm{X}_{2}=\text { Tingkat penjualan } \\
& \mathrm{a}=\text { Konstant }
\end{aligned}
$$

\subsection{Hasil Uji Hipotesis Statistik t (Parsial)}

Uji $t$ dilakukan untuk melihat besarnya pengaruh dan tingkat signifikan setiap variabel independen terhadap variabel dependen dilihat dari nilai signifikansi dari setiap variabel independen pada persamaan regresi. Hasil uji t pada penelitian ini menggunakan SPSS 23

\begin{tabular}{|c|c|c|c|}
\hline Model & $\mathrm{T}$ & Sig. & Keterangan \\
\hline (Constant) &,- 958 & ,349 & \\
\hline Pascabayar & 3,109 &, 000 & Berpengaruh Signifikan \\
\hline Penjualan & $-1,103$ & ,283 & Tidak Berpengaruh Signifikan \\
\hline
\end{tabular}
disajikan pada tabel 4.5 berikut ini :

\section{Tabel 4.5}

Hasil Uji t

\section{Coefficients $^{\mathrm{a}}$}

b. Dependent Variable : Piutang 


\section{Sumber : Data Olahan (2018)}

Berdasarkan hasil perhitungan SPSS uji t, dapat disimpulkan sebagai berikut :

a. Pascabayar $\left(\mathrm{X}_{1}\right)$ diketahui nilai t hitung sebesar 3,109 lebih besar daripada t Tabel sebesar 2,07961 dan dengan tingkat sig 0.00 yang berarti nilai sig $<(\alpha) 0.05$ maka dapat disimpulkan bahwa variabel pascabayar $\left(\mathrm{X}_{1}\right)$ secara parsial memiliki pengaruh yang signifikan terhadap variabel dependen. Maka demikian $\mathrm{H}_{0}$ ditolak, ini berarti bahwa pascabayar berpengaruh signifikan terhadap tingkat piutang usaha pada PT. PLN (Persero) Rayon Tanjung Batu.

b. Penjualan $\left(\mathrm{X}_{2}\right)$ diketahui nilai t hitung sebesar -1,103 lebih kecil daripada t Tabel sebesar 2,07961 dan dengan tingkat sig 0.283 yang berarti nilai sig $<(\alpha) 0.05$ maka dapat disimpulkan bahwa variabel penjualan $\left(\mathrm{X}_{2}\right)$ secara parsial tidak memiliki pengaruh yang signifikan terhadap variabel dependen. Maka demikian $\mathrm{H}_{0}$ diterima, ini berarti bahwa penjualan tidak berpengaruh signifikan terhadap tingkat piutang usaha pada PT. PLN (Persero) Rayon Tanjung Batu

\subsection{Hasil Uji Hipotesis Statistik F (Simultan)}

Uji F dilakukan untuk melihat besarnya pengaruh dan tingkat signifikan antara variabel independen secara simultan terhadap variabel dependen pada persamaan regresi. Hasil uji $\mathrm{F}$ pada penelitian ini menggunakan SPSS 23 disajikan pada tabel 4.6 berikut ini :

\section{Tabel 4.6}

Hasil Uji F

ANOVA $^{\mathrm{a}}$

\begin{tabular}{|c|c|c|c|c|c|}
\hline Model & $\begin{array}{l}\text { Sum of } \\
\text { Squares } \\
\end{array}$ & df & Mean Square & $\mathrm{F}$ & Sig. \\
\hline 1 Regression & $1,37969 \mathrm{E}+15$ & 2 & $6,89843 \mathrm{E}+14$ & 5,858 &, $000^{\mathrm{b}}$ \\
\hline Residual & $2,47306 \mathrm{E}+15$ & 21 & $1,17765 \mathrm{E}+14$ & & \\
\hline Total & $3,85274 \mathrm{E}+15$ & 23 & & & \\
\hline
\end{tabular}

a. Dependent Variable: Piutang

b. Predictors: (Constant), Penjualan, Pascabayar

Sumber : Data Olahan (2018)

Berdasarkan hasil perhitungan SPSS uji F, nilai F hitung yang diperoleh adalah sebesar 5,858 lebih besar daripada $\mathrm{F}$ Tabel sebesar 3,47 dan dengan tingkat sig 0.00 yang berarti nilai sig $<(\alpha) 0.05$ maka dapat disimpulkan bahwa seluruh variabel independen secara simultan memiliki pengaruh yang signifikan terhadap variabel dependen. 
Maka demikian $\mathrm{H}_{0}$ ditolak dan $\mathrm{H}_{\mathrm{a}}$ diterima yaitu terdapat pengaruh signifikan penggunaan listrik pascabayar dan tingkat penjualan terhadap piutang usaha. Hasil penelitian membuktikan bahwa model regresi dalam penelitian ini dapat digunakan untuk memprediksi faktor yang mempengaruhi tingkat piutang usaha.

\subsection{Hasil Koefisien Determinasi (R2)}

Hasil uji koefisien determinasi (R2) dengan menggunakan perhitungan SPSS 23 dari persamaan regresi disajikan pada tabel 4.7 dibawah ini

Tabel 4.7

Hasil Koefisien Determinasi (R2)

Model Summary ${ }^{b}$

\begin{tabular}{|c|r|r|r|r|}
\hline Model & \multicolumn{1}{|c|}{$\mathrm{R}$} & R Square & $\begin{array}{c}\text { Adjusted } \\
\text { R Square }\end{array}$ & $\begin{array}{c}\text { Std. Error of } \\
\text { The Estimate }\end{array}$ \\
\hline 1 &, $598^{\mathrm{a}}$ &, 358 &, 297 & 10851938,847 \\
\hline
\end{tabular}

Berdasarkan tabel 4.7 dapat diketahui nilai koefisien determinasi (R2) sebesar 0,358 atau $35,8 \%$. Artinya variabel pascabayar dan penjualan berpengaruh terhadap variabel piutang sebesar 35,8\%, sedangkan sisanya 64,2\% dijelaskan oleh variabel lain yang tidak dimasukkan dalam model regresi ini. Hal ini menunjukkan bahwa masih ada variabel lain diluar variabel pascabayar dan penjualan yang berpengaruh terhadap piutang.

\section{KESIMPULAN DAN SARAN}

\subsection{Kesimpulan}

Penelitian ini bertujuan untuk mengetahui pengaruh antara penggunaan listrik pascabayar dan tingkat penjualan terhadap piutang usaha pada PT. PLN (Persero) Rayon Tanjung Batu. Berdasarkan hasil analisis, maka kesimpulan yang diambil dari penelitian ini sebagai berikut :

1. Pascabayar berpengaruh terhadap piutang usaha pada PT. PLN (Persero) Rayon Tanjung Batu. Hal ini dibuktikan dengan nilai t hitung sebesar 3,109 lebih besar daripada t tabel sebesar 2,07961 dan signifikansi sebesar $0.00<$ dari tingkat signifikansi yang disyaratkan yaitu 0.05 . 
2. Penjualan tidak berpengaruh terhadap piutang usaha pada PT. PLN (Persero) Rayon Tanjung Batu. Hal ini dibuktikan dengan nilai t hitung sebesar -1,103 lebih kecil daripada $t$ tabel sebesar 2,07961 dan signifikansi sebesar $0.283>$ dari tingkat signifikansi yang disyaratkan yaitu 0.05 .

3. Pascabayar dan penjualan secara simultan berpengaruh terhadap piutang usaha pada PT. PLN (Persero) Rayon Tanjung Batu. Hal ini dibuktikan dengan nilai F hitung sebesar 5,858 lebih besar daripada $\mathrm{F}$ tabel sebesar 3,470 dan signifikansi sebesar $0.00<$ dari tingkat signifikansi yang disyaratkan yaitu 0.05 .

\subsection{Saran}

Dengan hasil analisis yang telah dikemukakan maka diharapkan perusahaan lebih dapat meningkatkan efektivitas pengendalian piutang, terutama saat kondisi recovery pasca krisis global seperti sekarang ini. Perusahaan hendaknya menjalankan kebijakan dalam pengumpulan piutang secara aktif atau pasif.

Perusahaan yang menjalankan kebijaksanaan secara aktif, maka perusahaan harus mengeluarkan uang yang lebih besar untuk membiayai aktivitas pengumpulan piutang, tetapi dengan menggunakan cara ini, maka piutang yang ada akan lebih cepat tertagih, sehingga akan lebih memperkecil jumlah piutang perusahaan.

Sebelum memberikan piutang sebaiknya perusahaan mencari informasi terlebih dahulu tentang keadaan dari calon pelanggan. Untuk mengurangi resiko piutang tak tertagih, sebaiknya perusahaan memperlihatkan 5C sebelum memberikan persetujuan penggunaan layanan pascabayar yaitu Character, Capacity, Capital, Collateral, dan Conditions. Bila pelanggan tidak dapat memenuhi kriteria tersebut, maka diarahkan ke layanan prabayar.

\section{KESIMPULAN}

Penelitian ini bertujuan untuk mengetahui pengaruh antara penggunaan listrik pascabayar dan tingkat penjualan terhadap piutang usaha pada PT. PLN (Persero) Rayon Tanjung Batu. Berdasarkan hasil analisis, maka kesimpulan yang diambil dari penelitian ini sebagai berikut :

1. Pascabayar berpengaruh terhadap piutang usaha pada PT. PLN (Persero) Rayon Tanjung Batu. Hal ini dibuktikan dengan nilai t hitung sebesar 3,109 lebih besar daripada t tabel sebesar 2,07961 dan signifikansi sebesar $0.00<$ dari tingkat signifikansi yang disyaratkan yaitu 0.05 .

2. Penjualan tidak berpengaruh terhadap piutang usaha pada PT. PLN (Persero) Rayon Tanjung Batu. Hal ini dibuktikan dengan nilai t hitung sebesar -1,103 lebih kecil daripada $t$ tabel sebesar 2,07961 dan signifikansi sebesar $0.283>$ dari tingkat signifikansi yang disyaratkan yaitu 0.05 .

3. Pascabayar dan penjualan secara simultan berpengaruh terhadap piutang usaha pada PT. PLN (Persero) Rayon Tanjung Batu. Hal ini dibuktikan dengan nilai $F$ hitung sebesar 5,858 lebih besar daripada $\mathrm{F}$ tabel sebesar 3,470 dan signifikansi sebesar $0.00<$ dari tingkat signifikansi yang disyaratkan yaitu 0.05 .

Dengan hasil analisis yang telah dikemukakan maka diharapkan perusahaan lebih dapat meningkatkan efektivitas pengendalian piutang, terutama saat kondisi recovery pasca 
krisis global seperti sekarang ini. Perusahaan hendaknya menjalankan kebijakan dalam pengumpulan piutang secara aktif atau pasif.

Perusahaan yang menjalankan kebijaksanaan secara aktif, maka perusahaan harus mengeluarkan uang yang lebih besar untuk membiayai aktivitas pengumpulan piutang, tetapi dengan menggunakan cara ini, maka piutang yang ada akan lebih cepat tertagih, sehingga akan lebih memperkecil jumlah piutang perusahaan.

Sebelum memberikan piutang sebaiknya perusahaan mencari informasi terlebih dahulu tentang keadaan dari calon pelanggan. Untuk mengurangi resiko piutang tak tertagih, sebaiknya perusahaan memperlihatkan 5C sebelum memberikan persetujuan penggunaan layanan pascabayar yaitu Character, Capacity, Capital, Collateral, dan Conditions. Bila pelanggan tidak dapat memenuhi kriteria tersebut, maka diarahkan ke layanan prabayar.

\section{DAFTAR PUSTAKA}

Fess, Warren Reeve. 2005. Pengantar Akuntansi. Alih Bahasa : Aria Faramita. Jakarta : Salemba Empat

Lukman Syamsudin. 2007. Manajemen Keuangan Perusahaan. Jakarta: PT Raja grafindo Persada.

M.Manullang. 2005. Dasar-Dasar Manajemen. Gajah Mada University Press P.O.BOX 14, Bulaksumur. Yogyakarta.

Narafin, M. 2006. Penganggaran Edisi Ketiga. Jakarta : Salemba Empat.

Peraturan Menteri ESDM Nomor 27 Tahun 2017 Tentang Tingkat Mutu Pelayanan dan Biaya Yang Terkait dengan Penyaluran Tenaga Listrik oleh Perusahaan PT. PLN (Persero).

Sugiyono. 2010. Metode Penelitian Pendekatan Kuantitatif, Kualitatif, dan R\&D. Bandung : Alfabeta 2012. Metode Penelitian Bisnis. Bandung : Alfabeta

Van Horne, James C and John Wachowisz. 2005. Fundamentals of Financial Management Prinsip-Prinsip Manajemen Keuangan. Penerjemah : Dewi Fitriasari dan Deny Arnos Kwary. Jakarta : Salemba Empat. 